\title{
Municipal Supervision and State Action Antitrust Immunity
}

\author{
Mark A. Perry门ं \\ "We are a nation not of 'city-states' but of States."
}

\section{INTRODUCTION}

In 1890, Congress declared illegal every "contract, combination ... or conspiracy, in restraint of trade."2 Fifty years later, the Supreme Court recognized an exception as deceptively simple as the statute itself: "the Sherman Act . . . must be taken to be a prohibition of individual and not state action."3 Thus was born the state action doctrine, which effectively immunizes anticompetitive conduct by states from federal antitrust liability. ${ }^{4}$

Under certain circumstances, private parties may also avail themselves of state action immunity. Otherwise, a plaintiff could defeat anticompetitive regulation by suing the regulated entity rather than the regulating authority. ${ }^{5}$ The Supreme Court has articulated a two-part test to evaluate such claims for immunity: the challenged activity must be pursuant to state authorization, and it must be " 'actively supervised' by the State itself." Since announcing this test, the Court has repeatedly cited lack of adequate

$\dagger$ B.A. 1988, The University of California at Berkeley; J.D. Candidate 1991, The University of Chicago.

1 Community Communications Co., Inc. v City of Boulder, 455 US 40, 54 (1982), citing 630 F2d 704, 717 (10th Cir 1980) (Markey dissenting).

3 Sherman Act $\$ 1,15$ USC \& 1 (1988).

${ }^{3}$ Parker $v$ Brown, 317 US 341, 352 (1943).

- The state action doctrine is also known as the Parker doctrine, after the case in which it was announced. Most of the litigated state action cases involve the Sherman Act, and this Comment will focus on that statute. The doctrine may also be invoked in similar proceedings under other antitrust statutes. See, for example, FTC $v$ Indiana Federation of Dentists, 476 US 447, 449, 465 (1986) (Federal Trade Commission Act § 5, 15 USC § 45(a)(1) (1988)).

- See Southern Motor Carriers Rate Conference, Inc. v United States, 471 US 48, 57 (1985): "We decline to reduce Parker's holding to a formalism that would stand for little more than the proposition that Porter Brown [the plaintiff in Parker] sued the wrong parties." (citing Cantor v Detroit Edison Co., 428 US 579, 616 n 4 (1976) (Stewart dissenting)).

- California Retail Liquor Dealers Ass'n v Midcal Aluminum, Inc., 445 US 97, 105 (1980) ("Midcal"); Southern Motor Carriers, 471 US at 57. 
supervision as grounds for denying state action immunity to private parties. ${ }^{7}$ Despite the importance of the supervision requirement to state action analysis, two questions remain unanswered: first, why should supervision be necessary at all, and second, what constitutes supervision by the "State itself"?

In Section I of this Comment, I describe the foundations and purpose of the Supreme Court's two-part state action test. I argue that while both prongs serve to ensure that the anticompetitive practice is consistent with state policy, courts rely more heavily on supervision than authorization because of concerns with judicial competence and federalism.

Because a wide range of governmental functions must be delegated, however, courts are forced to determine which governmental units can supervise private actors. The Supreme Court has declared that the state legislature and highest court are sovereign, and therefore supervision by those bodies is state supervision. In Section II, I discuss the issue of supervision by subordinate governmental entities, and conclude that state agencies can properly exercise supervisory powers; I then address the question of whether municipal supervision should satisfy the test for state action immunity.

The problem of municipal supervision generally arises in cases involving local services; most of the reported decisions involve taxicabs, garbage companies, and ambulance services. ${ }^{8}$ With taxicabs, as with most local services, the municipality has two options: it can allow anyone who qualifies to provide transportation services, or it could regulate the number of cabs and the price charged..$^{\circ}$ If the regulatory approach is chosen, a frustrated rival ${ }^{10}$ is likely to sue the incumbent firm ${ }^{11}$ in an attempt to gain entry; the question presented is whether and how the state action defense should be available when the putative supervisor is a municipality.

7 See, for example, 324 Liquor Corp. v Duffy, 479 US 335 (1987); Patrick v Burget, 486 US 94 (1988); see text at note 22.

See note 64 .

- See text at notes 64-85.

${ }^{10}$ A frustrated rival firm will be the most likely plaintiff because it will have the greatest incentive to sue. This Comment will assume that such a rival will be able to prove "antitrust injury." See Brunswick Corp. v Pueblo Bowl-O-Mat, Inc., 429 US 477 (1977). The arguments herein apply equally to other situations, such as suits brought by the government.

11 Frustrated rivals also frequently sue the city itself. For an introduction to the issues raised when the defendant is a municipality, see Herbert Hovenkamp and John A. Mackerron III, Municipal Regulation and Federal Antitrust Policy, 32 UCLA L Rev 719 (1985). This Comment will be concerned, however, only with private defendants. 
In Section III, I argue that municipal oversight should not satisfy the active supervision requirement. Private defendants should be required to show that they are supervised by the state itself, defined as the legislature, highest court, or an agency with statewide powers. This approach will best achieve the goals of the state action doctrine: promoting free competition and thereby enhancing consumer welfare, while at the same time preserving the comity relationship between the state and national governments that is mandated by our federal system. Finally, in Section IV, I discuss the applicability of other limitations on antitrust liability, and address objections to the position advocated.

\section{The Foundations and Purpose of the Active SUPERVISION REQUIREMENT}

The state action doctrine was announced by the Supreme Court in Parker $v$ Brown, ${ }^{12}$ which involved a system of state-enforced cartelization that severely curtailed California's raisin output. Relying on the concept of federalism, the Court held that the challenged activity did not violate the Sherman Act because the antitrust laws prohibit individual rather than state action.

In a dual system of government in which, under the Constitution, the states are sovereign, save only as Congress may constitutionally subtract from their authority, an unexpressed purpose to nullify a state's control over its officers and agents is not lightly to be attributed to Congress.

The state in adopting and enforcing the prorate program made no contract or agreement and entered into no conspiracy in restraint of trade or to establish monopoly but, as sovereign, imposed the restraint as an act of government which the Sherman Act did not undertake to prohibit. ${ }^{13}$

The federalism rationale has remained at the heart of the state action doctrine and is critical to understanding the proper

12317 US 341 (1943).

13 Id at 351-52. The other grounds for the decision were the legislative history and the language of the Sherman Act. Id at 351. The inconclusiveness of the legislative history of this law has often been cited, however; see, for example, Paul E. Slater, Antitrust and Government Action: A Formula for Narrowing Parker v. Brown, $69 \mathrm{Nw}$ U L Rev 71, 83 (1974) ("In truth, a full reading of the legislative history of the Sherman Act is not likely to help answer the Parker question one way or the other."). Furthermore, the broad language of the statute supports many other readings. Later courts have not relied on either the legislative history or the words of the Sherman Act to interpret or revise the state action doctrine. 
course of its development. But even though Parker exhibited extreme deference to the states, the Court was unwilling to exempt anticompetitive activities in which the government was only nominally involved. "[A] state does not give immunity to those who violate the Sherman Act by authorizing them to violate it, or by declaring their action is lawful."14 For forty years, however, a majority of the Court was unable to agree on the level of state involvement that would trigger state action immunity. ${ }^{15}$

Then, in Midcal, a unanimous Court announced a twopronged test to evaluate Parker claims. "First, the challenged restraint must be one clearly articulated and affirmatively expressed as state policy; second, the policy must be actively supervised by the State itself."16 Midcal involved a California statute that resulted in fixed minimum wine prices. The state authorized the price setting and enforced the resulting prices, but it did not engage in any review of the prices set. The Court held that the second prong of the newly announced test was not satisfied, and therefore that the state action doctrine was inapplicable. "The national policy in favor of competition cannot be thwarted by casting such a gauzy cloak of state involvement over what is essentially a private price-fixing arrangement."17

When applying the first prong of the Midcal test, the Court has drawn a distinction between sovereign and other state actors. In the former category are the legislature and the state's highest court; ${ }^{18}$ all other subdivisions of state authority are in the latter. The necessary authorization must come from the state as sovereign. ${ }^{19}$ This differential treatment of state organs is based on federalism. The federal government is bound to respect the regulatory choices of independent sovereigns, but there is no reason to pay such deference to non-sovereign state agencies or municipalities. ${ }^{20}$

\footnotetext{
14 Parker, 317 US at 351.

${ }^{15}$ See Frank H. Easterbrook, Antitrust and the Economics of Federalism, $26 \mathrm{~J} \mathrm{~L} \mathrm{\&}$ Econ 23, 26 (1983).

${ }^{18}$ Midcal, 445 US at 105 (internal quotations omitted), quoting City of Lafayette $v$ Louisiana Power \& Light Co., 435 US 389, 410 (1978) (plurality opinion).

${ }^{27} 445$ US at 106.

${ }_{18}$ The governor is probably also a sovereign actor, but the Supreme Court has expressly declined to decide this issue. Hoover $v$ Ronwin, 466 US 558, 568 n 17 (1984).

18 "Parker immunity is available only when the challenged activity is undertaken pursuant to a clearly articulated policy of the State itself, such as a policy approved by a state legislature ... or a State Supreme Court." Southern Motor Carriers, 471 US at 63 (citations omitted).

${ }^{20}$ Some commentators have criticized this distinction, noting that in other areas involving federalism, the Court has in fact deferred to municipalities. See, for example, Boulder, 455 US at 69-71 (Rehnquist dissenting); Easterbrook, $26 \mathrm{~J} \mathrm{~L} \&$ Econ at 36-38 \& n 31 (cited
} 
But if requiring sovereign authority ensures that the anticompetitive activity is in fact a policy to which the federal government owes deference, what is the purpose of the supervision requirement? Strictly speaking, requiring active supervision is unnecessary, or even contrary, to the federalism rationale. Once a state has made a considered choice to displace competition, one could argue that courts should defer to the state's decision, regardless of its method of implementation. ${ }^{21}$ Nevertheless, the Court has rigorously applied the supervision requirement, striking down three of the four regulatory schemes it has considered under this test. ${ }^{22}$

The continued vitality of the supervision requirement represents an attempt by the Court to reconcile federalism concerns with the practical problems inherent in delegating regulatory power: a private party could carry out an initially authorized scheme in a manner inconsistent with state policy. "Authorization," as a legal concept, means that an entity has certain enumerated powers by operation of law. When the entity exceeds the scope of that authorization, it loses any protection the law may have afforded. ${ }^{23}$ Applied to the state action context, this reasoning indicates that private anticompetitive activities that were not contemplated by the state should not receive the benefit of Parker immunity.

Federal courts, however, are ill-equipped to evaluate the congruence between the challenged activity and the purported state policy. First, a judicial attempt to examine the specific relationship between an activity and the state policy would raise serious procedural problems. Claims of state action immunity are usually raised

in note 15). This criticism fails in the state action field, however, for two reasons. First, the state-municipal distinction is consistent with the Sherman Act's economic goal of promoting allocative efficiency; to achieve this end, courts should construe exemptions as narrowly as possible. See text at notes 95-96. Furthermore, despite its federalism jurisprudence in other areas, the Court has consistently afforded less deference to municipalities than states in antitrust actions; the distinction is thus entrenched as precedent. See text at notes 44-52.

${ }^{21}$ William H. Page, Antitrust, Federalism, and the Regulatory Process: A Reconstruction and Critique of the State Action Exemption after Midcal Aluminum, 61 BU L Rev 1099, 1129 (1981).

22 Midcal, 445 US at 105-06; 324 Liquor, 479 US at 344-45; Patrick, 486 US at 101-06. In the fourth case the government conceded that the activity was actively supervised, so the Court did not have occasion to consider the issue. Southern Motor Carriers, 471 US at 62, 66. See also Indiana Federation of Dentists, 476 US at 465 (striking down private anticompetitive behavior, although it was claimed to be consistent with state policy, because of the lack of state supervision).

2s This is the concept of ultra vires acts, familiar from many areas of the law. See, for example, Pennhurst State School \& Hospital v Halderman, 465 US 89 (1984) (discussing relation between ultra vires acts by state officials and sovereign immunity). 
and decided at the pretrial stage, on motions to dismiss or for summary judgment. Since the state action doctrine excludes certain conduct from antitrust scrutiny, an inquiry into state policy and its relation to the challenged activity would raise difficult questions of fact and would obviate the Parker doctrine's effectiveness in disposing of meritless litigation. This harms not only the litigants, whose costs will increase, but also the public generally because of the added burden on the already-overworked judiciary.

More fundamentally, such an inquiry would involve federal courts in substantive review of state policy. It would be strange irony indeed if the Parker doctrine, founded on federalism, were interpreted to require federal involvement in state affairs. Determinations of whether a challenged activity accords with state policy should be made by the state itself. But a federal court presented with an antitrust claim must have some means of evaluating whether the state has in fact made that determination. The supervision requirement is such a device. The court can use the ongoing involvement of some state entity as a proxy for authorization. The state supervision requirement thus ensures that only those activities that accord with state interests, and thus can truly be called "state action," will escape federal antitrust liability.

This interpretation of the supervision requirement appears clearly in Hallie, where the Court held that when the defendant is a municipality, state supervision need not be shown. ${ }^{24}$ The Court reasoned that the supervision requirement essentially serves an evidentiary function, to ensure that the actor is actually furthering a state policy rather than a private anticompetitive scheme. ${ }^{25}$ The Court argued that since municipalities are presumed to be acting for the public good, evidence of supervision was not necessary; the requirement of state authorization provided an adequate safeguard..$^{26}$

The same day, however, the Court decided Southern Motor Carriers, holding that both Midcal requirements remain fully applicable to private parties. ${ }^{27}$ The Court explained that the active supervision requirement is necessary to ensure "that a State's actions will immunize the anticompetitive conduct of private parties only when the 'state has demonstrated its commitment to a pro-

\footnotetext{
24 Town of Hallie v City of Eau Claire, 471 US 34 (1985).

${ }^{25}$ Id at 46-47.

${ }^{28}$ Id.

${ }^{27} 471$ US at 57.
} 
gram through its exercise of regulatory oversight." "28 Private parties are treated differently than municipalities because of the greater probability that private actors behave anticompetitively for their own benefit. ${ }^{29}$ The additional requirement of active supervision ensures that the state is sufficiently concerned with the scheme that competition should give way to comity. ${ }^{30}$

\section{Supervision by Subordinate Governmental Entities}

States are composed of legislative, executive, and judicial branches; they encompass numerous agencies and departments; and they include many local governmental units such as counties, school districts, and municipalities. Each of these units of government is in some way a part of the "state itself," but they are not all equal for purposes of state action analysis. Only sovereign entities can provide the requisite authorization, ${ }^{31}$ but can non-sovereign state organs satisfy the second Midcal requirement-active supervision?

\section{A. State Agencies}

State agencies do not act in a sovereign capacity, and therefore cannot authorize anticompetitive conduct. In Goldfarb, for example, the Virginia State Bar had promulgated a minimum fee schedule and required lawyers to follow it as part of the ethical code. ${ }^{32}$ Although the association was a state agency, the Court held that lawyers following the fee schedule were not immune from antitrust liability. The Court declared that only the state acting as sovereign could supply such immunity; because neither the legislature nor the state supreme court had done so, the state action doctrine was inapplicable. ${ }^{38}$ This view was followed in Southern Motor Carriers, where the private defendants' actions were authorized by a state

28 Id at $61 \mathrm{n} 23$, quoting Phillip Areeda and Donald F. Turner, 1 Antitrust Law 12 213a at 73 (Little, Brown, 1978).

20 "We may presume ... that the municipality acts in the public interest. A private party, on the other hand, may be presumed to be acting primarily on his or its own behalf." Hallie, 471 US at 45 (footnote omitted).

so "This supervision requirement prevents the State from frustrating the national policy in favor of competition by casting a 'gauzy cloak of state involvement' over what is essentially private anticompetitive conduct." Southern Motor Carriers, 471 US at 57, quoting Midcal, 445 US at 106.

"See text at notes 18-19.

32 Goldfarb v Virginia State Bar, 421 US 773 (1975).

ss Id at 790-91. 
agency; the Court nevertheless required authorization by the legislature or state supreme court. ${ }^{34}$

However, state agencies can provide supervision sufficient to satisfy the second prong of the Midcal test. The Fifth Circuit in Southern Motor Carriers, for example, found that the requirement was satisfied because the state Public Service Commission actively supervised the defendants' activities. ${ }^{35}$ In the Supreme Court the government conceded that the agency supervision was sufficient, and the Court therefore analyzed only the authorization requirement. ${ }^{36}$ And in Patrick, the defendants claimed that two different state agencies supervised their conduct. ${ }^{37}$ The Court held that the supervision requirement was not satisfied because of the specific procedures and practices of the respective agencies; ${ }^{38}$ significantly, the Court did not hold that agency supervision of private conduct is per se insufficient. ${ }^{38}$ Furthermore, the lower courts have uniformly held that agency supervision satisfies Midcal. ${ }^{40}$

The authorization and supervision requirements are treated differently for practical reasons. The Court requires sovereign authorization because otherwise the federal government would owe no deference to the anticompetitive policy. But to require the legislature or state high court to supervise all properly authorized activity would be an administrative nightmare. Because the active supervision requirement calls for substantive review by a responsible authority, ${ }^{41}$ requiring sovereign supervision would clog the legislature or the courts with grievances about competition.

Authorizing state agencies to supervise the activity, on the other hand, ensures that aggrieved parties have a forum in which to air their complaints; at the same time, the goals of federalism are furthered because the state agency acts in the state's interest and enforces state policy. ${ }^{42}$ State agencies are in the best position

34 471 US at $62-63$.

s5 702 F2d 532, 539 \& n 12 (5th Cir 1983), rev'd on other grounds, 471 US 48 (1985).

${ }^{36} 471$ US at 63,66 .

37 The agencies were the state Board of Medical Examiners and the state Health Division. Patrick, 486 US at 101.

${ }^{38}$ See text at notes $100-01$.

39 See Phillip E. Areeda and Herbert Hovenkamp, Antitrust Law II 212.7 at 884 (Little, Brown, Supp 1988) ('Patrick suggests that 'active supervision' means that a state agency reviews specific decisions of private parties on their substantive merits and not merely on their procedural adequacy." (emphasis added)).

to See, for example, New England Motor Rate Bureau, Inc. v FTC, 908 F2d 1064, 1077 (1st Cir 1990); Benson v Arizona State Board of Dental Examiners, 673 F2d 272, 275 (9th Cir 1982); see also Shahawy v Harrison, 875 F2d 1529, 1535 (11th Cir 1989).

11 See text at notes 97-103.

62 See Kenneth Culp Davis, 1 Administrative Law $\S 3: 15$ at 208 (KC Davis, 2d ed 1978) (task of the legislature is to formulate "major policies and main outlines," whereas the "rel- 
to evaluate the application of state policy to particular instances of anticompetitive conduct. They can and should make the determination whether the challenged activity is "authorized" by the state; the federal antitrust court can then limit its inquiry to whether the agency is in fact exercising its duty to oversee the private parties. This two-step approach ensures that the activity is pursuant to state policy and at the same time affords sufficient deference to state decisions and processes.

\section{B. Municipalities}

Like agencies, municipalities are not sovereign; therefore, they may not authorize anticompetitive conduct. ${ }^{43}$ But they are unlike state agencies because of their parochial nature, and it is not clear whether their supervision of private parties can satisfy the second prong of the Midcal test.

\section{Municipal supervision in the Supreme Court.}

Three of the state action cases decided by the Supreme Court involved municipalities: Lafayette, ${ }^{44}$ Boulder, ${ }^{45}$ and Hallie. ${ }^{46} \mathrm{Al}-$ though they involve municipalities as defendants rather than as supervisors, these cases illustrate the Court's attitudes toward municipal governments. The Court has consistently, and rightly, refused to extend the same deference to municipalities as it does to states. ${ }^{17}$ Economic choices made by municipal governments might harm some consumers, either by design or effect. The state action doctrine acknowledges this possibility at the state level, but for reasons of comity leaves state regulations unchallenged. At the municipal level, however, no such political benefit is achieved. "To permit municipalities to be shielded from the antitrust laws [absent state authorization] would impair the goals Congress sought to achieve by those laws, without furthering the policy underlying the Parker 'exemption.' "48

ative details" are best left to administrative agencies).

is See, for example, Boulder, 455 US at 53-54.

4435 US 389 (1978) (municipal utility company not ipso facto immune from antitrust challenge because of its governmental nature).

4s 455 US 40 (1982) ("home rule" powers granted by state constitution do not confer state action immunity).

471 US 34 (1985) (municipal regulation pursuant to proper state authorization covered by Parker doctrine).

${ }^{47}$ See Lafayette, 435 US at 412 (plurality opinion): "Cities are not themselves sovereign; they do not receive all the federal deference of the States that create them."

48 Lafayette, 435 US at 415 (plurality opinion) (citation omitted). 
The Supreme Court's opinions firmly establish that a municipality is not free to implement an independent regulatory regime. Rather, municipalities are constrained by the principles of competition and federalism. Any municipal regulation must comply with one or the other: it must be independently congruent with antitrust policy, or it must be pursuant to state authorization and hence exempt under the Parker doctrine. ${ }^{48}$ If municipalities are thus so limited in their own anticompetitive activities, it follows a fortiori that their power to regulate private parties must be similarly limited.

In Hallie, the Court stated in a footnote that "where state or municipal regulation [of] a private party is involved . . . active state supervision must be shown." Although this language seems to decide the issue of municipal supervision in the negative, commentators either ignore it or discount its importance, arguing that the issue of municipal supervision was not before the Court and that the footnote therefore refers to some other issue. ${ }^{\text {s1 }}$ It is at least as plausible, however, that the Court has concluded that municipal supervision is not sufficient for state action purposes.

The natural reading of the Hallie footnote is that it requires state supervision even when municipal regulation is involved. This reading is supported by Patrick, the Court's most recent opinion discussing the active supervision requirement:

The requirement is designed to ensure that the state action doctrine will shelter only the particular anticompetitive acts of private parties that, in the judgment of the State, actually further state regulatory policies. To accomplish this purpose, the active supervision requirement mandates that the State exercise ultimate control over the challenged anticompetitive conduct. $^{\text {s2 }}$

Supervision by a municipality would deprive the state of "ultimate control" over the challenged activity; allowing municipal supervision to satisfy the Midcal test thus directly conflicts with the plain language of the Patrick decision.

19 See Boulder, 455 US at 57: "[W] hen the State itself has not directed or authorized an anticompetitive practice, the State's subdivisions in exercising their delegated power must obey the antitrust laws." (quoting Lafayette, 435 US at 416 (plurality opinion)).

so 471 US at 46 n 10 (emphasis added).

51 See, for example, Areeda and Hovenkamp, Antitrust Law I 212.7 at 158 (cited in note 39): "[T]he context indicates that the Court was contrasting private with public activity-requiring supervision of the former but not of the latter-rather than discussing the identity of the supervisor."

62486 US at 100-01 (emphasis added). 
2. Municipal supervision in the lower courts.

The lower courts are split on the question of municipal supervision. Most courts that have considered the issue allow municipal supervision to satisfy the Midcal test, although usually with little discussion. For example, in Trinity Ambulance, the court held that the state action doctrine immunized the grantees of an exclusive municipal ambulance franchise where the state authorized the city to provide for ambulance services. ${ }^{63}$ The court deemed municipal supervision sufficient, noting that the "official supervision of the ambulance companies in this case is at least equivalent in degree to the official supervision of private defendants that was deemed sufficient" in Southern Motor Carriers. ${ }^{54}$ In a similar case plaintiffs challenged the grant of an exclusive franchise to one taxicab company. ${ }^{55}$ The court surveyed the Supreme Court state supervision cases and summarily concluded that the private defendants were immune because the city supervised their conduct. ${ }^{56}$

The Sixth Circuit, in contrast, has held that municipal supervision is insufficient. The leading case is Riverview Investments, in which the plaintiff alleged that the refusal of a municipally controlled development corporation to issue revenue bonds restrained trade by preventing the creation of new businesses. ${ }^{57}$ After the district court granted summary judgment for the defendant, the Court of Appeals reversed and remanded. In its initial remand order, the Sixth Circuit instructed the district court to consider the state action doctrine, and specifically whether the municipality supervised the challenged conduct. The plaintiff petitioned for a rehearing, and the court criticized its earlier language regarding municipal supervision: "In light of Town of Hallie and Southern Motor Carriers, that statement may not be a completely accurate statement of the law." 58 The court therefore modified the order to require state supervision. ${ }^{58}$

ss Trinity Ambulance Service, Inc. v G \& L Ambulance Service, Inc., 625 F Supp 142 (D Conn 1985), aff'd per curiam, 787 F2d 86 (2d Cir 1986).

84625 F Supp at 145.

ss Woolen v Surtran Taxicabs, Inc., 615 F Supp 344 (N D Tex 1985).

so Id at 350 .

${ }^{87}$ Riverview Investments, Inc. v Ottawa Community Improvement Corp., 774 F2d 162, modifying 769 F2d 324 (6th Cir 1985).

${ }^{68} 774$ F2d at 163.

39 On a later appeal in the same case, the court affirmed the state-municipal distinction. 899 F2d 474, 476 n 2, 478-81 (6th Cir 1990). 
Riverview Investments was interpreted and followed in City Communications. ${ }^{60}$ There, the plaintiff, a frustrated rival, sued the successful bidder for a cable television franchise. The defendant argued that it was exempt under the state action doctrine because it was supervised by the city of Detroit. The court held: "While some courts do permit municipal supervision to meet the state supervision requirement [citing Trinity Ambulance], that is not the law of this circuit. In Riverview, the Sixth Circuit expressly held that private parties seeking state action immunity must demonstrate that they have been supervised by the state, not by the municipality."

The Riverview Investments court gave no reason for its decision, other than its belief that it was following Hallie and Southern Motor Carriers. And the City Communications court merely followed circuit precedent; it offered no independent analysis of why municipal supervision should not satisfy Midcal. Similarly, in both Trinity Ambulance and Woolen, as well as in other cases allowing municipal supervision to satisfy $\mathrm{Midcal}^{\mathbf{6 2}}$ the courts did not offer any justification for their holdings. The courts also uniformly fail to recognize or address the problems inherent in municipal regulation.

The Supreme Court's opinions indicate that municipal supervision should not be sufficient to confer Parker immunity, but the Court has not definitively addressed the issue. The lower courts are divided, and, more importantly, none offers a compelling reason why one approach should be preferred. A principled solution to the question of municipal supervision must give appropriate weight to both the economic and the political considerations embodied in the state action doctrine.

\section{Problems with Municipal Supervision and a Proposed Solution}

Municipal supervision should not be sufficient to confer antitrust immunity on private actors. ${ }^{63}$ Rather, ultimate supervision by

\footnotetext{
${ }^{60}$ City Communications, Inc. $v$ City of Detroit, 660 F Supp 932, denying reconsideration of 650 F Supp 1570 (E D Mich 1987).

e1 Id at 935 .

${ }^{62}$ See, for example, Vartan v Harristown Development Corp., 655 F Supp 430, 437-38 (M D Pa 1987), aff'd by order, 838 F2d 1206 (3d Cir 1988); see also Savage v Waste Management, Inc., 623 F Supp 1505 (D SC 1985) (holding supervision by county sufficient).

ss This Comment assumes that the private party is in fact engaging in anticompetitive activity that would, absent state action immunity, violate the Sherman Act.
} 
a state agency should be required. This approach will enhance consumer welfare by increasing competition, and it conforms with the federalism framework established by the Supreme Court in prior state action cases.

A. Regulation or Competition: Problems with Municipal Supervision

A simplified model based on the provision of airport taxicab services demonstrates the difficulties inherent in municipal supervision of private actors. ${ }^{64} \mathrm{~A}$ municipality has two basic options when evaluating the provision of taxicab services to arriving passengers. The first is regulation: the city can grant one company an exclusive franchise to provide taxi service; some form of rate regulation would also be necessary. ${ }^{65}$ The alternative is competition: the city can allow individual taxi drivers (or companies) to bargain directly with consumers for the provision of transportation services. ${ }^{68}$

The regulatory model, under which the municipality contracts with one firm for the benefit of its citizens, involves some transaction and information costs. But since only one "deal" is required, the net cost will be much lower than under the competitive model; this is the primary benefit of regulation. ${ }^{67}$ The administrative cost of the system is the principal cost of the regulatory model. Because the licensed company will have monopoly power, it may charge

\footnotetext{
a4 Airport taxi franchising is the most common source of litigation involving municipal supervision. See, for example, Independent Taxicab Drivers' Employees $v$ Greater Houston Trans. Co., 760 F2d 607 (5th Cir 1985) (Houston Intercontinental Airport); Woolen, 615 F Supp 344 (Dallas/Fort Worth Regional Airport); Charley's Taxi Radio Dispatch Corp. $v$ SIDA of Hawaii, Inc., 562 F Supp 712 (D Hawaii 1983) (Honolulu International Airport); All American Cab Co. v Metropolitan Knoxville Airport Authority, 547 F Supp 509 (E D Tenn 1982) (McGhee-Tyson Airport [Knoxville]). Similar exclusive franchises are often granted for trash-hauling companies, see Tom Hudson \& Assoc., Inc. $v$ City of Chula Vista, 746 F2d 1370 (9th Cir 1984); ambulance services, see Trinity Ambulance, 625 F Supp 142; and taxicab services generally, see Golden State Transit Corp. $v$ City of Los Angeles, 726 F2d 1430 (9th Cir 1984). The analysis in such cases is substantially similar to that presented in the text.

${ }^{85}$ The city need not grant such a license to only one company; there may be two (or ten). The analysis is similar, however, and the single-firm model will be used for the sake of simplicity.

os Of course, under neither approach will there be pure competition or pure regulation; any intermediate approach, however, will share the characteristics and problems of the polar examples used for illustration.

${ }^{67}$ See Mark W. Frankena and Paul A. Pautler, An Economic Analysis of Taxicab Regulation 3-4 (FTC Bureau of Economics Staff Report, 1984). Regulation also reduces price discrimination by drivers. Id at 3 . See text at notes $75-82$ for a discussion of other rationales for local services regulation.
} 
consumers more than they would have to pay if taxi services operated in a free market. The city must therefore regulate the rates which taxicabs can charge and set up a system of monitoring and enforcement to ensure compliance. ${ }^{68}$ In addition, the city must police the industry to prevent unauthorized entry.

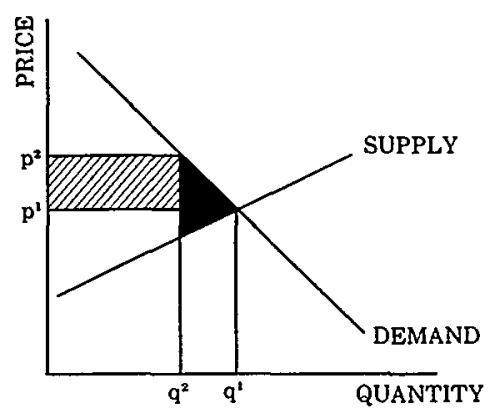

Such a regulatory regime will result in allocative inefficiency, regardless of whether the taxi companies are permitted to charge a supracompetitive price. A system of entry regulation will shift the quantity of available taxis from q1 (the competitive equilibrium) to q2.69 The regulators then have two choices: the price can be allowed to rise to $\mathrm{p} 2$, or they can impose a ceiling at $\mathrm{p} 1$. Under the first approach, the taxicab companies gain the transfer payment from consumers represented by the hatched rectangle. Society as a whole, however, loses the consumers' and producers' surplus, represented by the shaded triangle. ${ }^{70}$ If the price is held at $\mathrm{p} 1$, on the other hand, society still bears the deadweight loss represented by the shaded triangle; in addition, the difference in price between $\mathrm{p} 1$ and $\mathrm{p} 2$ will be borne by consumers in the form of increased waiting time. ${ }^{71}$ Waiting time will increase because, at the lower fare p1, more customers will demand the services of the same number of taxis. In both cases, the effective price to consumers is $\mathrm{p} 2 ;^{72}$ at that price some will engage in inefficient substitution.

68 The city may be able to enter into a long-term contract with a fixed price provision, but monitoring costs as well as the renegotiations that are inevitable in light of changing economic conditions will produce a cost structure similar to regulation.

60 The assumption that entry regulation will reduce available quantity is confirmed by the empirical observation that after entry regulations are eliminated, the number of total taxicabs and cab-hours of service increases. See Frankena and Pautler, An Economic Analysis of Taxicab Regulation at 116-17 (cited in note 67).

70 Jack Hirshleifer, Price Theory and Applications 249-50 (Prentice-Hall, 3d ed 1984).

71 Id at 221-25, 227-31. While the transfer payment from consumers to producers disappears under a price ceiling system, society incurs additional social costs, represented by the hatched rectangle, in the form of waiting time and inefficient allocation of taxicab resources.

${ }^{72}$ Frankena and Pautler, An Economic Analysis of Taxicab Regulation 117-18 (cited in 
The competitive model contemplates an unlimited number of providers bargaining directly with consumers of taxi services. Consumers benefit because the system is not run by the municipality, which reduces administrative costs and frees revenue for other uses. An unregulated market will also result in a supply-demand equilibrium, eliminating the deadweight loss and enhancing allocative efficiency. The costs of the competitive model are primarily the transaction costs incurred by requiring a large number of individual bargains. ${ }^{73}$ There is also an information cost problem; consumers must expend resources to determine which company best suits individual requirements. ${ }^{74}$

How will the municipality choose between these alternative models? As a first approximation, it is unclear why a municipality would ever choose a system of regulation. Its own administrative costs are much higher than those under a competitive regime, and consumers will likely be worse off because of a reduction in choice and an increase in price. Furthermore, the lost consumer and producer surplus constitutes a deadweight loss to society.

The traditional explanations for economic regulation are natural monopoly, excessive competition, transaction costs, and scarce resources. ${ }^{75}$ Only the excessive competition and transaction costs rationales apply to most local services. But the excessive competition theory has been largely discredited; the complaint usually stems from the incumbent firms who want governmental protection from the ordinary rigors of the marketplace. ${ }^{76}$ And while the

note 67), note that the increased number of taxis following entry deregulation is accompanied by a decrease in consumer waiting time, suggesting that the fare ceilings were set below the market-clearing price (p2). The same study also concludes that in at least one area fares declined following deregulation, id at 115-16, which suggests that the regulated fare was higher than the competitive fare (p1). The actual money fare under a system of entry regulation, therefore, is probably between $\mathrm{p} 1$ and $\mathrm{p} 2$, while the remaining difference is borne by the consumers as waiting time.

7s The bargained-for fare, of course, must be set ex ante to avoid the problems of bilateral monopoly. Transaction costs are reduced to the extent that firms set fares at a uniform level within the firm, rather than for each rider.

74 This problem is reduced, at least in the airport taxi market, by the rule or custom of taking the first cab in the queue. Also, if safety and competence factors continue to be regulated, consumers should be generally indifferent among cab companies. In the absence of price regulation, any differences in quality of service (for example, age of car or air conditioning) could be reflected in the price.

${ }^{76}$ Thomas D. Morgan, Jeffrey L. Harrison, and Paul R. Verkuil, Economic Regulation of Business 15-20 (West, 2d ed 1985); see also Stephen Breyer, Regulation and its Reform ch 1 (Harvard, 1982).

76 See, for example, Breyer, Regulation and its Reform at 29-32 (cited in note 75). 
transaction costs problem (particularly pollution-related externalities) may be real, simple entry restrictions may not be the efficient solution. ${ }^{77}$

Some local services, such as cable television, have many features of prototypical natural monopolies like electricity delivery. ${ }^{78}$ But the economies of scale and scope would seem to be exhausted relatively quickly. For example, cable operators in Houston divided the city into several cable areas, each with a separate provider. ${ }^{79}$ Although the cable operators had illegally conspired in dividing the market, the Fifth Circuit found that the division itself was reasonable. Furthermore, competition for the initial franchise and renewal contracts can produce the beneficial effects of a competitive market, even when a single provider is optimal, without the administrative or efficiency costs of a regulatory scheme. ${ }^{80}$

A more persuasive explanation for local services regulation is a producer capture theory: regulated industries benefit from regulation, and thus play an instrumental role in the enactment of regulatory legislation..$^{81}$ Existing taxi companies want as few competitors as possible and will expend resources to convince the municipality to grant them an exclusive contract. ${ }^{82}$ By using the

${ }^{27}$ See Frankena and Pautler, An Economic Analysis of Taxicab Regulation at 42-43 (cited in note 67). Another possible explanation is that the municipality is attempting to achieve some social goal other than the optimal provision of taxicab services. This story is at least plausible in some cases where public welfare concerns loom large (for example, ambulances), but it is difficult to discern policy concerns large enough to outweigh the efficiency losses caused by regulating the taxi industry. The competitive model contemplates continued regulation of insurance, vehicle safety, and so forth; see generally Deborah L. Lyons and Michael C. Ahn, Taxi Regulation in a Free Entry Market 41-61 (US Dept of Transportation, 1983), describing the Washington, D.C. taxicab regulatory scheme. The issue is thus what social goal is served by entry and fare/rate regulations. Of course, the regulators just may not know what they are doing. Even if the "stupid regulators" explanation is intuitively appealing, however, we cannot make any predictions or conclusions from this rationale.

${ }^{78}$ See Richard A. Posner, The Appropriate Scope of Regulation in the Cable Television Industry, 3 Bell J Econ \& Mgmt Sci 98, 110-11 (1972). banc).

${ }^{79}$ Affiliated Capital Corp. $v$ City of Houston, 735 F2d 1555, 1563 (5th Cir 1984) (en

${ }^{80}$ See Harold Demsetz, Why Regulate Utilities?, 11 J L \& Econ 55, 57 (1968) (pervasive rate regulation of public utilities would be unnecessary in a world of competitive franchising because the firms would compete away any supracompetitive profits in the attempt to enter the market; later supracompetitive pricing would be checked by potential competition for the renewal rights). But see Tom Hudson \& Assoc., 746 F2d at 1373-74 (city awarded exclusive trash-hauling franchise without any competitive bidding).

${ }^{81}$ See Richard A. Posner, Theories of Economic Regulation, 5 Bell J Econ \& Mgmt Sci 335 (1974). For a recent example, see Thomas W. Hazlett, Who's Behind the Cable Scam, Wall St J A10 (Mar 30, 1990): "The cable industry's lobbyists are attempting to forestall what they fear most-competition-by compromising on what they fear less-regulation."

${ }^{82}$ Professor Stigler puts this point very strongly. "We propose the general hypothesis: every industry or occupation that has enough political power to utilize the state will seek to 
political process to gain market power, participants in the regulated industry acquire the ability to exact monopoly rents because they are protected from price competition by later entrants.

Empirical evidence supports this interpretation. One nationwide study of taxicabs, for example, concluded that "[ $t]$ here is no persuasive economic rationale for some of the most important regulations," particularly entry control and minimum fares. ${ }^{83}$ The study found that abolition of such restrictions resulted in more firms, less concentrated markets, more cabs in service, and lower fares. ${ }^{84}$ The conclusion that the taxicab industry has captured the regulatory process is inescapable. ${ }^{85}$

Of course, municipal regulation does not always represent capture and should not be condemned categorically. Rather, the high likelihood of capture in the municipal context may in itself be sufficient reason not to embrace a pure hands-off approach. The Supreme Court has recognized the dangers inherent in municipal regulation: "If municipalities were free to make economic choices counseled solely by their own parochial interests and without regard to their anticompetitive effects, a serious chink in the armor of antitrust protection would be introduced at odds with the comprehensive national policy Congress established."86

Allowing municipal supervision of our taxi company would be just such a chink. If we accept the capture theory, or even concede that it is possible, then what safeguard is left to protect consumers? Only their votes. But while the lack of a supervision requirement for municipal defendants ${ }^{87}$ reflects in part the effectiveness of voter control over local government, the same considerations do not hold for anticompetitive activities of private parties.

First, consumers face a classic collective action problem: a small, organized interest group will systematically prevail over a

control entry." George J. Stigler, The Theory of Economic Regulation, 2 Bell J Econ \& Mgmt Sci 3, 5 (1971). Note that there may be one or several firms in the industry; regardless of the number of incumbents, they will seek to exclude later entrants into the market.

os Frankena and Pautler, An Economic Analysis of Taxicab Regulation at 155 (cited in note 67).

84 Id at 156. For a detailed account of regulatory capture in the Chicago taxicab market, see Edmund W. Kitch, Marc Isaacson, and Daniel Kasper, The Regulation of Taxicabs in Chicago, $14 \mathrm{~J} \mathrm{~L} \mathrm{\&} \mathrm{Econ} 285$ (1971). For other empirical studies of capture, see Posner, 5 Bell J Econ \& Mgmt Sci at 336-37 \& n 3 (cited in note 81).

ss See Ronald F. Kirby, et al, Para-Transit: Neglected Options for Urban Mobility 63 (US Dept of Transportation, 1974). Municipal taxicab regulation has in fact become a stock illustration of regulatory capture. See, for example, Herbert Hovenkamp, Legislation, WellBeing, and Public Choice, 57 U Chi L Rev 63, 87-88 (1990).

se Lafayette, 435 US at 408 (plurality opinion).

87 See text at notes 24-26. 
large, disorganized one, even though the resulting regulation harms the large group or results in a social loss. ${ }^{88}$ The taxicab industry, with narrow objectives, can influence the regulatory regime to further its own ends; the consumers, who bear the costs of the system, are too widely dispersed for effective counteraction. Moreover, there is little reason to believe that consumers in fact recognize anticompetitive behavior in local services when it occurs, because the marginal effect on the individual consumer is relatively small.

The efficacy of democratic control also depends on the identity of the actor. In the case of public trash collection, for example, the city's name on the trucks and bills serves as a constant reminder to the consumer of the responsible party. If the consumer does in fact recognize the anticompetitive behavior, the ill will engendered reflects directly on the city itself. The likelihood of a public outcry would be considerably less if a private company, ostensibly unassociated with the city, were to engage in the same activity.

The collective action problem thus severely undermines the effectiveness of voter control; information costs, both in recognizing the inefficient behavior and in identifying the responsible actor, exacerbate the ineffectiveness of the voter control mechanism. ${ }^{89}$

\section{B. The Role of Antitrust Law: A Proposed Solution}

1. The correct interpretation of state supervision.

For the reasons identified, primarily the ease of producer capture at the municipal level and the ineffectiveness of democratic control, some review process is necessary to protect the welfare of consumers and promote competition and efficiency in local services markets. Recognizing the potential problems with municipal supervision does not imply, however, that the antitrust laws should be used to require substantive review of local policies by federal courts. ${ }^{90}$

Instead, courts evaluate antitrust immunity claims under a procedural test, based on state authorization and state supervision. This approach examines only the objective relationship between

\footnotetext{
${ }^{88}$ See Mancur Olson, Jr., The Logic of Collective Action 29 (Harvard, 1965).

89 The same problems, particularly the small marginal effect of anticompetitive local services regulation, seriously weaken the argument that consumers can "vote with their feet" by moving; the marginal benefits from such a move will often be outweighed by its costs. For an elaboration of the voting through mobility argument, see Easterbrook, $26 \mathrm{~J} \mathrm{I}$ \& Econ at 33-35 (cited in note 15).

${ }^{20}$ See text following note 23.
} 
the state and the private defendant; it thus avoids the pitfalls of substantive review while ensuring that the challenged activity is truly "state action" rather than merely a "gauzy cloak" of state involvement. This same procedural test can solve the problems of municipal supervision. The authorization must always come from a sovereign state entity; the supervision requirement should not be deemed satisfied unless the supervisor is part of the state itself.

The state legislature and supreme court are sovereign, and thus constitute "the state"; in their administrative capacity, state agencies can also represent the state for supervisory purposes because they serve the state's ends and promote state policies. A municipality, on the other hand, is subject to pressures that may produce policies at odds with those of the state. The first Midcal prong does not adequately protect the state's interest because very general grants of power can satisfy the authorization requirement; ${ }^{21}$ the state may not contemplate an anticompetitive implementation of regulatory authorization.

The Supreme Court recently stated that

[t]he active supervision prong of the Midcal test requires that state officials have and exercise power to review particular anticompetitive acts of private parties and disapprove those that fail to accord with state policy. Absent such a program of supervision, there is no realistic assurance that a private party's anticompetitive conduct promotes state policy, rather than merely the party's individual interests. ${ }^{22}$

The state agency can review the challenged activity to determine whether it is in fact pursuant to state authorization and consistent with state policy. Particularly in contrast to federal courts, state agencies are well qualified for this role. A court presented with an antitrust claim can then evaluate the relationships among the state entities. If a state agency supervises the private party, the court can conclude that the activity furthers a state policy, and thus that federalism precludes antitrust liability.

If supervision by the municipality were deemed sufficient to confer immunity, however, no procedural means would exist to ensure the challenged activity's consistency with state policy. Municipal supervision simply does not serve the evidentiary function of the supervision requirement because the court cannot infer from it that the challenged activity accords with state policy. Thus munic-

\footnotetext{
91 See note 108.

${ }^{22}$ Patrick, 486 US at 101 (emphasis added).
} 
ipal supervision should not satisfy the Supreme Court's requirement that all private anticompetitive activity be actively supervised by the "State itself."

Deference to the "State itself" represents a compromise between the antitrust laws and principles of federalism. The antitrust laws have as their foundation Congress's desire to protect competition; ${ }^{94}$ courts should promote this objective except when specific exemptions control. One such exemption is for state action, founded on federalism. But governmental regulation may decrease allocative efficiency, contrary to the aims of the antitrust laws. Thus, "[t] he Parker doctrine represents an attempt to resolve conflicts that may arise between principles of federalism and the goals of the antitrust laws, unfettered competition in the marketplace."95

In contrast, the federal government owes no deference to municipalities; there is no such animal as municipalism. As with all exemptions to the antitrust laws, the state action doctrine should be construed as narrowly as possible to avoid frustrating the purposes of the Sherman Act. ${ }^{96}$ Only activity that is truly "state action" should escape antitrust scrutiny. Thus, the conduct of private actors in the local sphere should be subject to antitrust scrutiny, unless the state itself (the legislature, highest court, or an agency with statewide powers) actively supervises the challenged activity.

\section{What state supervision entails.}

This supervisory requirement need not be onerous or wasteful. The Supreme Court's state action cases establish that "active su-

${ }^{93}$ The states want more control over Parker immunity. For example, during hearings on the Local Government Antitrust Act of 1984 (see text at notes 118-28), the representative of the National Conference of State Legislatures ("NCSL") testified as follows: "The Boulder decision expressly left to the states the power to immunize local activities from federal antitrust liability. NCSL is not in favor of rolling back this portion of the opinion because of our view that in a federal system of dual sovereigns, immunization decisions properly belong to the states." HR Rep No 98-965, 98th Cong, 2d Sess 13 n 19 (1984) (statement of State Legislator Dick Hemstad) (emphasis added). The approach proposed in this Comment is thus consistent with the policy of deference to state interests, the foundation of the state action doctrine.

${ }^{94}$ See Robert H. Bork, The Antitrust Paradox 66 (Basic, 1978) (describing the Sherman Act as a "consumer welfare prescription"); quoted with approval in Reiter $v$ Sonotone Corp., 442 US 330, 343 (1979).

${ }^{95}$ Southern Motor Carriers, 471 US at 61.

${ }^{9}$ See, for example, Lafayette, 435 US at 398-400; Group Life \& Health Insurance Co. $v$ Royal Drug Co., Inc., 440 US 205, 231 (1979). See also Abbott Laboratories v Portland Retail Druggists Ass'n Inc., 425 US 1, 11 (1976) (Robinson-Patman Act exceptions should be strictly construed). 
pervision" is not to be taken in its literal sense. A requirement of actual state involvement in the anticompetitive conduct itself would create large administrative costs with no obvious benefits. While it is convenient and customary to refer to state supervision of the challenged activity, the Midcal test actually requires supervision only of the policy underlying that activity. ${ }^{97}$ So stated, it is clear that actual state involvement in the challenged activity is unnecessary to satisfy the Midcal requirement. The supervision requirement actually entails a substantive review process whereby a state organ has the opportunity to evaluate the challenged activity; the subsequent ratification, modification, or invalidation of the activity ensures that the conduct really is "state action."

In Midcal, for example, the Court struck down the challenged price-fixing scheme because the state merely authorized price setting and enforced the prices. The Court provided a list of what the state did not do, indicating some practices that are important in evaluating a claim of adequate supervision. These factors include establishing prices, reviewing the reasonableness of the prices set, regulating terms of contracts, and monitoring market conditions. The Court noted that, in short, the state did not engage in any "pointed reexamination" of the program..$^{98}$ Thus although the state had something to do with the system, its involvement was merely a "gauzy cloak" that would not shield the defendants from antitrust liability. ${ }^{\text {.9 }}$

Patrick offers the clearest example of the Court's view of the supervision requirement. The plaintiff was a physician who had been suspended following a peer review investigation. He sued, claiming the process was an illegal restraint of trade. The defendants successfully asserted a state action defense in the lower courts, but lost in the Supreme Court. Although the defendants claimed that three different state organs supervised the challenged activity, the Court held that the requirements of active supervision were not met.

First, the state Health Division had power to review general hospital procedures. The Court held that because it could not supervise or review individual peer review decisions, it did not actively supervise the conduct at issue. ${ }^{100}$ Second, the state Board of

97 Midcal, 445 US at 105. All references to "active supervision" in this Comment are meant to be read in this light.

${ }^{98}$ Id at 106.

9 Id.

100486 US at 102-03. 
Medical Examiners required notification of any peer review procedures. But since the board lacked power to review or revise them, the Court held that it did not supervise the conduct either. ${ }^{101}$ Finally, the defendants argued that the state courts were available for the plaintiff to air his grievances, and that therefore they supervised the challenged activity. The Court disagreed, because judicial review would be limited to procedural issues in the investigation; the substance of the disciplinary process was beyond the state courts' jurisdiction and competence. ${ }^{102}$

The Patrick decision suggests that to satisfy Midcal, some state organ must have the following powers: actual authority to review the contested conduct, power to revise or reverse the challenged decision, and the ability to conduct a substantive inquiry into the activities being reviewed. ${ }^{103}$ Only if all three conditions are met can there truly be "active state supervision."

Requiring a state agency to supervise our taxi company therefore means only that consumers and potential competitors have a state forum in which to voice their objections to the current regime. The state is thus given the opportunity to ratify-or strike down-the challenged activity, ensuring that it is in fact consistent with state policy. The municipality can continue to be the active decisionmaker, and in the majority of cases the agency will remain uninvolved. But the existence of a review procedure provides a check on the local producers that would not exist if municipal supervision were sufficient to confer antitrust immunity.

\section{Promoting competition through state supervision.}

Consumers will benefit from the proposed approach because it will spur regulatory reform, resulting in more competitive local services markets. Since the Supreme Court's Boulder decision, which held that municipalities are not ipso facto immune under the Parker doctrine, the threat of antitrust liability has proven to be a major factor in taxicab deregulation. ${ }^{104}$ The Federal Trade Commission has attempted to encourage regulatory reform in taxicab

101 Id at 103.

102 Id at 103-05.

${ }^{103}$ See Areeda and Hovenkamp, Antitrust Law If 212.7 at 884 (cited in note 39); accord, New England Motor Rate Bureau, Inc. v FTC, 908 F2d 1064, 1074 (1st Cir 1990); Matter of Ticor, 1989 FTC LEXIS 80, *17-18.

104 See, for example, L. Carol Shaw, et al, 1 Taxicab Regulation in U.S. Cities 93-94 (US Dept of Transportation, 1983) (antitrust concerns were one of five "motivating catalysts" for cities contemplating or adopting changes in the regulatory structure); see also id at $80-81$. 
markets through the use of antitrust prosecutions. ${ }^{105}$ Although such efforts have met with mixed success, they illustrate the powerful coercive effect of antitrust liability. ${ }^{106}$

Pressure on the municipality will be largely ineffective, however, if municipal supervision can satisfy the Midcal test. The dominant firms, who as organized interest groups will have more influence than the large number of consumers who could benefit from the change, ${ }^{107}$ will vigorously oppose reform, and the city itself will rarely face antitrust liability, since its activities need only be pursuant to state authorization. ${ }^{108}$ Municipal politicians thus have little incentive to embrace deregulation, because presumably they benefit more from promoting the interests of the regulated industry than those of consumers. ${ }^{109}$ Since by hypothesis these firms wield sufficient political influence to secure anticompetitive municipal regulation initially, it is disingenuous to suppose that

108 The FTC filed complaints against the cities of Minneapolis and New Orleans, alleging that their regulations resulted in anticompetitive taxicab markets in violation of $\S 5$ of the Federal Trade Commission Act, 15 USC $\$ 45$ (1988). See Matter of the City of Minneapolis, 105 FTC 304 (1985); Matter of the City of New Orleans, 105 FTC 1 (1985). After the suit was filed, Minneapolis revised its taxicab regulations; the FTC found that "[t]hese changes offer the prospect of preventing the anticompetitive conduct alleged in the complaint by strongly facilitating new entry into the Minneapolis taxicab market" and therefore withdrew the complaint. 105 FTC at 309. The New Orleans action was thwarted, however, when the state legislature enacted a statute that specifically empowered cities to regulate entry and fares in the taxicab market; the FTC was therefore forced to withdraw its complaint. 105 FTC at 5-6.

${ }^{100}$ Edmund W. Kitch, Taxi Reform-The FTC Can Hack It, Regulation 13, 15 (May/ June 1984), argues that using the antitrust laws in this manner is an effective means of increasing competition and removing "clogs on interstate commerce imposed by local regulation." See also Frank H. Easterbrook, Foreword: The Court and the Economic System, 98 Harv L Rev 4, 51 (1984) (when interest group pressures result in anticompetitive regulation with interstate consequences, "courts should become more active in preserving competition under the auspices of federal antitrust law"). Several other cities did in fact deregulate taxis in the wake of the FTC actions. Timothy J. Muris, The Federal Trade Commission at Seventy-five (unpublished manuscript; on file with $\mathrm{U}$ Chi $\mathrm{L}$ Rev).

${ }^{102}$ Olson, The Logic of Collective Action at 65 (cited in note 88); see also text at notes 81-89. In Shaw, et al, 2 Taxicab Regulation in U.S. Cities at 81, 86 (cited in note 104), the authors provide an example of the stakes involved: regulatory reform in Sacramento, California increased the number of taxicab companies from three to nineteen and reduced the dominant firm's market share from $70 \%$ to less than $50 \%$. Although in this instance deregulation triumphed despite the opposition of the market leader, the incentive to oppose deregulation is obviously great.

108 State authorization is routinely found in state action cases. Although Boulder held that the general grant of "home rule" powers was not sufficient authorization, see 455 US at 52-57, little more specificity is required. For example, an Illinois statute empowering municipalities to "prescribe [the] compensation" of taxicab drivers has been held to authorize the city of Chicago's entry restrictions and fare regulations for taxicabs generally. Campbell $v$ City of Chicago, 823 F2d 1182, 1184-85 (7th Cir 1987).

100 See text at notes $81-89$. 
supervision by the same municipality will lessen the harmful impact of that policy on consumers.

Requiring state supervision alters the political dynamics, potentially resulting in more efficient regulation. First, the regulated industry may well have less influence at the state than at the local level. ${ }^{110}$ State regulators will be able to review the situation more objectively and are likely to be more proficient in assessing the effects of regulatory policies. ${ }^{111}$ Municipal regulators are frequently either inexpert political appointees, or entities such as police departments for which economic regulation is a secondary function. Although municipal regulators may have more day-to-day knowledge of the regulated industry, the risk of regulatory capture offsets these potential efficiency gains. Any particularized knowledge of consumer needs is useless if the regulator acts in the interest of the industry. Finally, exposing the private parties to antitrust liability serves as a disincentive to oppose deregulation. Under the proposed approach, it is more likely that inefficient regulation will be revised, thereby enhancing consumer welfare by promoting competition in local services markets.

\section{Criticism and Response}

\section{A. Applicability of Other Limitations on Antitrust Liability}

The state action doctrine, of course, is not the only device available to private defendants seeking to escape antitrust liability. This section briefly discusses the two other important limitations on antitrust liability and their relation to the proposed approach.

\section{The Noerr-Pennington doctrine.}

Certain political activity is exempted from antitrust liability under the Noerr-Pennington doctrine. ${ }^{112}$ Specifically, attempts to influence the legislature to pass laws or the executive to enforce them are not subject to Sherman Act scrutiny. ${ }^{113}$ Similarly, attempts to influence agencies, as well as recourse to the courts, are protected activities. ${ }^{114}$ Some courts have interpreted the Noerr-

110 See text at note 130 .

11 One commentator has termed this phenomenon "economies of expertise." Timothy J. Brennan, Local Government Action and Antitrust Policy: An Economic Analysis, 12 Fordham Urb L J 405, 410 (1984).

112 See Eastern Railroad Presidents Conf. $v$ Noerr Motor Freight, Inc., 365 US 127 (1961); United Mine Workers of America v Pennington, 381 US 657 (1965).

${ }^{113}$ See California Motor Transport Co. $v$ Trucking Unlimited, 404 US 508, 510 (1972).

114 Id. An important limitation of the Noerr-Pennington doctrine is the "sham" excep- 
Pennington doctrine to immunize private parties in municipal supervision cases merely because some governmental actor (the municipality) is involved. The reasoning usually proceeds as follows: the municipality itself is exempt because of the state action doctrine, while the private defendant is exempt because the regulatory scheme is political activity, for which it cannot be held liable under Noerr-Pennington. ${ }^{115}$

This reasoning is flawed. Even if the initial lobbying for the franchise is protected political activity, there is no reason to hold subsequent anticompetitive practices exempt from the antitrust laws. To do so would render nugatory the entire state action doctrine as applied to private parties. If the mere involvement of a political process sufficed to remove the resultant activity permanently from antitrust scrutiny, no private anticompetitive scheme could be challenged successfully despite its harmful effects on consumers. The defendant in such a suit would not need to prove either state authorization or state supervision, but could merely point to the involvement of some governmental entity and cite Noerr-Pennington. Such a result obviously conflicts both with the $\mathrm{Su}-$ preme Court's antitrust framework and the goal of protecting consumers.

The correct application of the Noerr-Pennington doctrine to the issue of municipal supervision requires a distinction between the acquisition of anticompetitive power and its subsequent use. Under Noerr-Pennington, the private party seeking anticompetitive regulation or legislation is exempt from the antitrust laws,;16 legitimate attempts to influence the political process are the very activities that the doctrine was designed to protect. Once a private party has gained the power to act anticompetitively, however, the inquiry should shift to the Parker doctrine. ${ }^{117}$ Independent anticompetitive activities cannot properly be characterized as politi-

tion: private parties can lose the immunity by abuse of the political process. See Noerr, 365 US at 144; see generally Trucking Unlimited, 404 US at 511-16. Whether a regulated entity's attempts to capture the regulatory process could be considered an abuse is a question of fact; this Comment assumes that the initial pressure on the agency or government is protected activity. Persistent opposition to new entrants by incumbent firms, however, such as might occur in the taxicab industry, may constitute an antitrust violation not covered by Noerr-Pennington. See Trucking Unlimited, 404 US 508 (denying immunity for such conduct).

${ }^{115}$ See, for example, Independent Taxicab Drivers' Employees, 760 F2d at 612-13.

116 Such activity, absent Noerr-Pennington, could be actionable as a conspiracy under $\S 1$ or an attempt to monopolize under $\S 2$ of the Sherman Act. 15 USC $\S 1,2$ (1988).

${ }_{117}$ For an argument similar to that presented in the text, with examples to illustrate its application, see Areeda and Hovenkamp, Antitrust Law 1212.8 at 161-63 (cited in note 39). 
cal action; Noerr-Pennington is simply inapplicable. Rather, if the actor is to escape antitrust liability, the private activity must be actively supervised by the state itself and thereby qualify for the state action exemption.

\section{The Local Government Antitrust Act.}

In 1984, Congress passed the Local Government Antitrust Act ("LGAA"), ${ }^{118}$ which exempts local governments from monetary damage liability in antitrust cases. ${ }^{110}$ The LGAA also exempts certain private conduct from monetary damages. ${ }^{120}$ Congress was concerned that recent Supreme Court decisions, particularly Boulder, had rendered municipal liability under the state action doctrine uncertain, and that the threat of large damage awards was both unnecessary and potentially harmful. ${ }^{121}$ This congressional action does nothing, however, to alter the analysis presented in this Comment; in fact, the legislative history supports the position advocated.

First, anticompetitive behavior is fully actionable after the passage of the LGAA; only the treble damage liability has been removed. ${ }^{122}$ In actions arising out of local services regulation, consumer welfare is enhanced by cessation of the anticompetitive practices. Significantly, injunctive relief remains available to antitrust plaintiffs under the LGAA; ${ }^{123}$ frustrated rivals or other interested parties can therefore sue in equity to redress anticompetitive practices or gain entry into a market. In such a case, the principles set forth above should be followed. Furthermore, private parties lose the protection afforded by the LGAA if they engage in anticompetitive activity not contemplated by the local government. ${ }^{124}$

${ }_{118}$ Pub L No 98-544, 98 Stat 2750 (1984), codified at 15 USC §§ 34-36 (1988).

11815 USC \& 35 (1988).

12015 USC $\$ 36$ (1988).

121 HR Rep No 98-965 at 7-11 (cited in note 93). The Director of the FTC's Bureau of Competition at the time has argued that the LGAA was passed partly in response to the FTC's taxicab enforcement attempts (see notes 105-06). Muris, The Federal Trade Commission at Seventy-five (cited in note 106).

122 The LGAA "eliminates certain damage suits under the Clayton Act without altering ... the substantive antitrust law." HR Rep No 98-965 at 2 (cited in note 93) (emphasis added). Treble damages are ordinarily available in antitrust actions under $\S 4$ of the Clayton Act, 15 USC $\S 15$ (1988).

${ }^{12 s}$ Injunctive relief is provided for under $\S 16$ of the Clayton Act, 15 USC $\S 26$, which is not affected by the LGAA.

${ }^{134}$ See S Rep No 98-593, 98th Cong, 2d Sess 7-8 (1984); HR Rep No 98-965 at 21-22 (cited in note 93). 
The legislative history of the LGAA supports the position that municipal supervision does not satisfy the Midcal state action test. In the Conference Report that accompanied the final version of the LGAA, the joint committee explained that "the conferees intend that Parker and subsequent cases interpreting it shall apply by analogy to the conduct of a local government in directing the actions of non-governmental parties, as if the local government were a state."125 Such an extension of supervisory power would be completely unnecessary if municipalities already had such power under the state action doctrine. Congress thus understood Parker not to apply to private activities supervised by a municipality and included such activities in the LGAA because they would otherwise be subject to the full force of the antitrust laws.

Examples used by the drafters to illustrate application of the law confirm this interpretation. The House Report contemplates the grant of an exclusive franchise to an airport restaurant, ${ }^{126}$ while the Senate Report discusses an exclusive ambulance franchise. ${ }^{12 z}$ Their inclusion in the legislative history indicates that both houses of Congress believed that private activities protected from competition by local government would not be exempt from liability under the state action doctrine: parties immunized by Parker would have no need of protection under the LGAA. ${ }^{128}$

\section{B. Objections to the Proposed Solution}

Although disallowing municipal supervision as a basis for private party immunity in antitrust cases promotes both the economic and the political aims of the antitrust laws, objections can of course be advanced. In this section, I respond to three such challenges. First, although agencies are themselves prone to capture, agency supervision is preferable to municipal oversight. Second, the recurrent argument that the Parker doctrine-and the approach I advocate-allows courts to substitute their economic judgment for that of the states should be discounted. Finally, the proposed solution strains neither the competence of the agencies nor the status quo of political power.

${ }^{225}$ HR Rep No 98-1158, 98th Cong, 2d Sess 3 (1984) (emphasis added); see also HR Rep No 98-965 at 25 (cited in note 93) (additional views of Representative Brooks): "This extension to private firms is an attempt to express and codify the existing court developed 'state-action' doctrine[] at the local level."

${ }^{226}$ HR Rep No 98-965 at 21 (cited in note 93).

${ }^{127} \mathrm{~S}$ Rep No $98-593$ at 7 (cited in note 124).

${ }^{128}$ See HR Rep No 98-965 at 19 (cited in note 93) (state agencies are not included in the LGAA because "[s]uch entities receive antitrust immunity directly from the "state-action' doctrine"). 


\section{Agency capture.}

The argument for disallowing municipal supervision rests on the possibility of capture by the regulated private parties. State agencies, however, are also subject to capture; arguably, the proposed solution will merely cause private actors to shift the focus of their lobbying efforts. While this objection has some force, disallowing municipal supervision will nevertheless have both federalism and efficiency benefits.

First, agency capture may be one of the necessary consequences of the federalism regime created by the state action cases. Parker itself, for example, involved a scheme proposed-and largely controlled-by raisin growers to restrict output and thereby raise the price of raisins. But the Court held that some anticompetitive state activities must be outside the sphere of federal antitrust law. Recognizing a zone of exempted activities necessarily implies that some conduct otherwise actionable will escape liability. The boundary of this zone, however, has been drawn at the state level; there is no reason for courts to ignore anticompetitive conduct that is not state action. ${ }^{129}$

Furthermore, shifting the focus of inquiry from the municipal to the state level should result in fewer successful capture attempts. The producers of local services may well wield considerable influence in the city in which they operate; at the state level their lobbying abilities will be markedly diminished. ${ }^{130}$ Any reduction in producers' ability to capture the regulatory process will directly benefit consumers by making efficient regulation more likely.

It may be objected that if we are concerned with regulatory capture, then the state action doctrine should be interpreted to prevent capture, rather than merely make it more difficult. Thus, some courts have suggested that the municipality's exemption should extend to private parties so long as the municipality remains the effective decisionmaker. One court framed the issue as follows: "Were the City of Detroit's decisions that permitted the defendants to retain their exclusive cable television franchise made by the City, or did [the defendants] have so much influence that the decisions were effectively those of the private defendants?"131

129 See text at notes $18-20$.

130 See Federalist 10 (Madison) in Clinton Rossiter, ed, The Federalist Papers 77, 8384 (New Amer Lib, 1961) (justifying a federal government on the grounds that larger political units are less susceptible to capture by "factions").

${ }^{131}$ City Communications, Inc. $v$ City of Detroit, 660 F Supp 932, 935, denying reconsideration of 650 F Supp 1570 (E D Mich 1987). 
The court held that if the city effectively made the decisions, its immunity would extend to the private defendants; but if they had captured the regulatory process then state-not municipal-supervision would be required. ${ }^{132}$ The appeal of such a test lies in its recognition of the capture problem and its straightforward response. ${ }^{133}$

Relying on capture itself to define the boundaries of the state action doctrine is nonetheless problematic. First, it requires federal courts to engage in a substantive inquiry into the relationship between the private defendant and the municipality-the type of inquiry that the state action doctrine seeks to avoid at the state level. A test based on capture is also potentially ineffective. Although the theory of capture has long been recognized and is generally accepted by economists, ${ }^{134}$ actual instances are difficult to demonstrate. In any individual case, it may be impossible to prove the existence or nonexistence of capture. Such a test would therefore require a presumption either in favor of or against regulatory capture. But for the very reason that a presumption is necessary-the difficulty of proving capture-creating such a presumption will often be dispositive of the issue. The effect of such a rule, therefore, would be largely the same as simply allowing or disallowing municipal supervision to satisfy Midcal.

Another objection to agency review is that important policy decisions are removed to an unelected, and therefore unaccountable, entity. This argument fails, however, for at least two reasons. First, it rests on the faulty premise that decisions made by municipalities are accountable to the electorate; as demonstrated, problems of collective action and information costs seriously undermine municipal accountability. This objection also fails to recognize the accountability of agencies to the state legislature, and hence derivatively to the electorate as a whole; evidence suggests that through appropriations, appointments, and other devices agency action is effectively checked by elected government offi-

132 Id. In a later proceeding, the court held that the city was in fact the effective decisionmaker and granted summary judgment for the defendants. 695 F Supp 911, 915 (E D Mich 1988).

${ }^{133}$ One commentator has proposed a similar approach, in which local regulation escapes antitrust scrutiny only if it is tailored to a specific market failure, and the defendant could disprove a presumption of capture. The nonexistence of capture in both cases is the touchstone that confers antitrust immunity. John Shepard Wiley Jr., A Capture Theory of Antitrust Federalism, 99 Harv L Rev 713 (1986).

${ }^{134}$ See generally Hovenkamp, 57 U Chi L Rev at 86-89 (cited in note 85). 
cials. ${ }^{135}$ The suggested approach may therefore actually enhance democratic control.

\section{Creeping Lochnerism?}

Critics have labeled the Supreme Court's state action jurisprudence a return to substantive due process, with economic efficiency substituted for liberty of contract. ${ }^{136}$ The implication is that only those economic regulations of which courts approve will be considered state action. Because the proposed approach will result, at least in the short run, in the invalidation of some regulatory schemes, this criticism will likely be made.

The legal distinction between Lochner-type intervention and Parker review is profound. Anticompetitive activity is made affirmatively illegal by the Sherman Act; without the state action doctrine, courts could invalidate under the Supremacy Clause all regulation that restrained trade. The Parker exemption is thus a safe harbor for anticompetitive state regulation. In sharp contrast to the era of substantive due process, the Court here refrains from using power it already has, rather than extending its authority beyond that granted by statute or the Constitution. ${ }^{137}$

Nevertheless, it may be argued that by selective application, the Parker doctrine permits courts to engage in an otherwise impermissible substantive review of the merits of economic regulation. Although it is true that some lower courts have erroneously decided state action cases in this way, ${ }^{138}$ the Supreme Court has consistently followed an exclusively process-oriented approach. ${ }^{139}$ The two-pronged Midcal test requires a court to find authorization and supervision; both are ascertainable without any inquiry into the substance of the challenged activity. Regulation that satisfies Midcal is considered consistent with state policy and therefore exempt as state action; all other regulation is subject to antitrust review.

135 Barry R. Weingast and Mark J. Moran, Bureaucratic Discretion or Congressional Control? Regulatory Policymaking by the Federal Trade Commission, $91 \mathrm{~J}$ Pol Econ 765, 790-93 (1983).

${ }^{138}$ See, for example, Hovenkamp and Mackerron, 32 UCLA L Rev at 758-65 (cited in note 11). The famous case of Lochner $v$ New York, 198 US 45 (1905), is representative of the era of substantive due process, during which the Court used the Due Process Clause to strike down economic regulation.

${ }^{137}$ See Lochner, 198 US at 75-76 (Holmes dissenting).

${ }^{138}$ See, for example, Gold Cross Ambulance and Transfer $v$ City of Kansas City, 705 F2d 1005, 1011-15 (8th Cir 1983).

${ }^{130}$ Cantor v Detroit Edison Co., 428 US 579 (1976), is a possible exception. But the case, which spawned five separate opinions, has had little precedential influence. 
The proposed solution to the problem of municipal supervision is therefore divorced from substantive judicial review of economic policy. Federal antitrust courts are required, and permitted, to examine only the objective relationship between the state and the private actor. If the state review process qualifies as active supervision, then state action immunity attaches; otherwise the defendant cannot claim the exemption. Judgments regarding the necessity or desirability of the challenged activity have no place in either the Midcal scheme or the approach proposed in this Comment. ${ }^{140}$

\section{Local autonomy.}

Justice Rehnquist, dissenting in Boulder, noted that it would be "rather odd to require municipal ordinances to be enforced by the State rather than the city itself."141 Some lower courts have seized on this language to justify municipal supervision, ${ }^{142}$ and one commentator has offered a similar criticism: "it would be implausible to rule that a city may regulate, say, taxi rates but only if a state agency also supervises the private taxi operators." ${ }^{143}$ That is, of course, precisely what I have proposed, but these objections are inapposite.

Justice Rehnquist's criticism is certainly valid; state enforcement of local policies would be both anomalous and duplicative. But the approach suggested in this Comment does not entail state enforcement of local regulation; rather, it requires state ratification, following a substantive review, of private anticompetitive conduct. The distinction goes beyond semantics because enforcement implies affirmative state participation in the routine affairs of local government. Ratification, on the other hand, requires only state

140 Boulder itself illustrates the force of this point: the challenged activity was a threemonth moratorium on expansion by the monopoly cable provider so that the city could solicit competitive bids; despite its welfare-enhancing effect the Court was forced to strike down the regulation because it had no procedural means to evaluate its consistency with state policy. 455 US at $45-46,54-56$. In contrast, the challenged activity in Orrin Fox was a horizontal market division of auto dealerships, which would be a per se violation of the Sherman Act absent state involvement. Because the Court found sufficient state involvement, it upheld the restraint despite its harmful effect on consumers. New Motor Vehicle Board of California v Orrin W. Fox Co., 439 US 96, 98, 109-11 (1978). If the Court truly were engaging in Lochner-type review based on economic efficiency, it would have decided both cases the opposite way.

${ }^{241}$ Boulder, 455 US at $71 \mathrm{n} 6$ (Rehnquist dissenting).

${ }^{142}$ See, for example, Gold Cross Ambulance, 705 F2d at 1014-15.

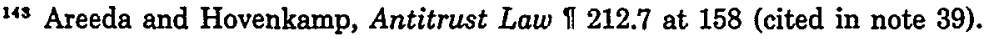


approval (or disapproval) of the anticompetitive activity if and when it is challenged. ${ }^{144}$ Thus, because the proposed approach leaves the decisional powers of local governments undisturbed, concerns of state overinvolvement in local government activities are unfounded. 148

Professor Areeda's "implausibility" argument is similarly unpersuasive. It rests on an assumption of duplicative regulation that does not apply to the suggested approach. More importantly, his very example is refuted by empirical evidence: at least $20 \%$ of the states do in fact regulate taxicabs at the state level, many of them in conjunction with local regulation. ${ }^{146}$ Indeed, it would not be "implausible" to require other local services to undergo similar state supervision. All of the activities involved in local services regulation are closely analogous to activities currently regulated at the state level. Taxicab and garbage truck regulation, for example, could be reviewed by the same state agency that has jurisdiction over trucking and similar activities. Ambulances could be supervised by a state health agency; cable operators by the state public utility agency; and so forth.

Requiring a state agency to review local regulation would strain neither the agency's competence nor the status quo of political power. At the same time, municipalities can manage their own affairs subject only to occasional state review. This argument allows federal courts to adjudicate Parker claims by private parties with a minimum of intrusion into state affairs, while at the same time protecting consumer welfare.

\section{CONCLUSION}

The state action doctrine is a compromise between two often contradictory policies: the economic goal of the antitrust laws to secure the benefits of free competition for all consumers, and the political aim of federalism, which requires the federal government to defer to state regulatory choices despite their anticompetitive effects.

The supervision requirement is a procedural test to aid federal courts in ascertaining whether a private defendant is in fact pursuing a valid state policy. To fulfill the supervision requirement and

\footnotetext{
14 See text at note 103.

115 A related objection, that municipal decisions are best made at the municipal level, fails for the same reason. For an example of this objection, see Brennan, 12 Fordham Urb $\mathrm{L}$ $J$ at $407-09$ (cited in note 111).

${ }^{146}$ Shaw, et al, 1 Taxicab Regulation in U.S. Cities 7-11 (cited in note 104).
} 
avail itself of state action immunity, a private defendant should be required to show that it is supervised by the state itself, defined as the legislature, highest court, or an agency with statewide powers. Municipal supervision should not satisfy this test, because there is no assurance that the municipality is furthering state policy rather than the anticompetitive interests of the regulated entity. Limiting the state action doctrine in this way will enhance consumer welfare by promoting competition in local services markets, striking the correct balance between efficiency and federalism. 
, 